\section{Correlation of maternal BMI with fetal liver ultrasound measurements in Gestational Diabetes Mellitus}

Mirko Mackic ${ }^{1,2}$, Miroslava Gojnic ${ }^{3,4}$, Tomislav Stefanovic ${ }^{1}$, Jovana Paunovic ${ }^{3}$, Amira Fazlagic ${ }^{5}$, Igor Pantic ${ }^{3,6}$, Lazar Nejkovic $^{2}$, Milan Perovic ${ }^{2}$

${ }^{1}$ Hospital for Gynecology and Obstetrics, Clinical Hospital Centre „Zemun“, Belgrade, Serbia

${ }^{2}$ Clinic for Gynecology and Obstetrics "Narodni front", Belgrade,

Serbia

${ }^{3}$ University of Belgrade, Faculty of Medicine, Serbia

${ }^{4}$ Clinical Centre of Serbia, Clinic for Gynecology and Obstetrics, Belgrade, Serbia,

${ }^{5}$ Medison Clinic, Zemun, Belgrade, Serbia

${ }^{6}$ Institute of Medical Physiology, Belgrade, Serbia

\section{Abstract}

Gestational diabetes mellitus and maternal overweight and obesity are associated with increased risk for adverse maternal and perinatal outcomes, such as fetal overgrowth. Although most studies addressing the effects of maternal BMI on adverse outcomes include women with GDM, a little is known about associations between maternal BMI and fetal metabolic status evaluated by ultrasonography means. One of the ultrasound parameter of glycemic controlis the measurement of fetal liver length. Prospective study of 385 women with monofetal pregnancies and established risk for GDM underwent mid-trimester ultrasound exam, during which fetal liver length were measured. After exam, body mass index (BMI) was determined for each patient. Each participant underwent $100 \mathrm{~g}$ fasting oral glucose challenge test (oGTT) in order to confirm or to exclude diagnosis of GDM. There was a statistically highly significant positive correlation between the BMI and fetal liver length for the entire sample $(\mathrm{N}=385 ; \mathrm{p}<0.001$; $\mathrm{R}=+0.55)$ as well in the sample of GDM patients $(\mathrm{N}=96 ; \mathrm{p}<0.001 ; \mathrm{R}=+0.58)$ and controls $(\mathrm{N}=289$; $\mathrm{p}<0.001 ; \mathrm{R}=+0.33$ ). Maternal BMI has impact on fetal liver length assessed by ultrasound exam. This influence is even higher in GDM.

Keywords: gestational diabetes, fetal liver length, ultrasound, BMI

\section{Korelacija maternalnog BMI i ultrazvučno procenjenih dimenzija fetalne jetre u gestacijskom dijabetesu}

\author{
Mirko Mačkić1, ${ }^{1,2}$, Miroslava Gojnić3 ${ }^{3,4}$, Tomislav Stefanović ${ }^{1}$, \\ Jovana Paunović ${ }^{3}$, Amira Fazlagić ${ }^{5}$, Igor Pantic ${ }^{3,6}$, Lazar \\ Nejković², Milan Perović ${ }^{2}$ \\ ${ }^{1}$ Bolnica za ginekologiju i akušerstvo, Kliničko-bolnički centar \\ „Zemun“, Beograd, Srbija \\ ${ }^{2}$ Klinika za ginekologiju i akušerstvo „Narodni front““, Beograd, \\ Srbija \\ ${ }^{3}$ Univerzitet u Beogradu, Medicinski fakultet, Srbija \\ ${ }^{4}$ Klinički centar Srbije, Klinika za ginekologiju i akušerstvo, Beograd, \\ Srbija, \\ ${ }^{5}$ Medison klinika, Zemun, Beograd, Srbija \\ ${ }^{6}$ Institut za medicinsku fiziologiju, Beograd, Srbija
}

\section{Apstrakt}

Gestacioni dijabetes mellitus (GDM) i gojaznost trudnice nose povećan rizik neželjenih perinatalnih ishoda, kao što je ekcesivni fetalni rast. Iako su poznati neželjeni efekti povećanog maternalnog indeksa telesne mase (BMI) na neželjene ishode trudnoća komplikovanih GDM-om, malo se zna o vezi trudničkog BMI i metaboličkog statusa fetusa evaluiranog ultrasonografijom. Jedan od ultrazvučnih parametara glikemijske kontrole je merenje dužine fetalne jetre. Prospektivna studija je obuhvatila 385 trudnica sa jednoplodnom trudnoćom i postojanjem rizika za GDM. One su podvrgnute ultrazvučnom pregledu u drugom trimestru trudnoće (24. nedelja), kada je merena dužina fetalne jetre. Nakon pregleda, izračunat je BMI za svakog pacijenta, nakon čega su podvrgnuti testu oralnog opterećenja sa 100 g glukoze (oGTT), ne bi li postavili ili isključili dijagnozu GDM-a. Nađena je visoko statistički značajna korelacija BMI i dužine fetalne jetre za celu studijsku populaciju ( $\mathrm{N}=385 ; \mathrm{p}<0.001 ; \mathrm{R}=+0.55)$, ali $i$ za podgrupu trudnica sa GDM-om $(\mathrm{N}=96 ; \mathrm{p}<0.001$; $\mathrm{R}=+0.58)$ i podgrupu zdravih trudnica $(\mathrm{N}=289$; $\mathrm{p}<0.001 ; \mathrm{R}=+0.33$ ). Maternalni BMI ima uticaj na dužinu fetalne jetre, a taj uticaj je još izraženiji kod trudnica sa GDM-om.

Ključne reči: gestacijski dijabetes mellitus, dužina fetalne jetre, ultrazvuk, BMI 


\section{Introduction}

A new model for obesity prevention has come out in recent years, evolved from the idea that environmental aspects in early life and in utero can have profound influence on lifelong health ${ }^{1}$. Gestational diabetes mellitus (GDM) and maternal overweight and obesity are associated with increased risk for adverse maternal and perinatal outcomes, such as fetal overgrowth ${ }^{2}$. Many ultrasound parameters of glycemic and metabolic control are used today in monitoring of pregnancies complicated with GDM in terms of evaluation of maternal and fetal status and determining the timing of the institution of oral antidiabetic drugs or insulin 3,4 .

Fetal liver dimensions play a role in identifying fetal growth acceleration in diabetic pregnancies, representing the reflection of maternal metabolic status and risks to fetal development ${ }^{5,6}$. Maternal overnutrition, particularly in GDM, is responsible for fetal overnourishment, and consequently for fetal liver enlargement due to increased glycogen storage ${ }^{1}$.

The aim of our study was to test if there is correlation between maternal body mass index (BMI) and fetal liver length measured by ultrasound exam during the second trimester scan.

\section{Materials and Methods}

Prospective study of 385 women with monofetal pregnancies and established risk for GDM underwent mid-trimester ultrasound exam, during which fetal liver length were measured. The standard procedure for ultrasound liver measurement was used ${ }^{6}$. After exam, body mass index (BMI) was determined for each patient. Each participant underwent $100 \mathrm{~g}$ fasting oral glucose challenge test (oGTT) in order to confirm or to exclude diagnosis of GDM.

Statistical analysis of the data was performed using SPSS statistical software (IBM Corporation, Chicago, IL). Student's t-test was used for estimation of the difference between groups, and correlation analysis was done by calculating Pearson product-moment correlation coefficient.

\section{Results}

Our study involved 385 participants eligible for inclusion. Among them, 96 pregnant women were diagnosed with GDM and 289 had negative oGTT. The prevalence of GDM in our study population was $24.94 \%$. Mean BMI in hole study population was 26.122 and standard deviation (SD) was 4.576. Mean fetal liver length measured by ultrasound (FLL) was $33.756 \mathrm{~mm}$, and SD was 5.995 .

We found significant differences in BMI $(\mathrm{p}<0.01 ; \mathrm{t}=9.0373)$ and in FLL measurements as well between GDM and Non GDM participants as well $(\mathrm{p}<0.01 ; \mathrm{t}=17.9671)$, which is presented in table 1 .

\begin{tabular}{|l|l|l|}
\hline & BMI (SD) & FLL \\
\hline GDM & $29.446(4.800)$ & $40.78(5.53)$ \\
\hline Non GDM & $25.017(3.926)$ & $31.42(3.99)$ \\
\hline
\end{tabular}

Table 1. BMI and FLL in GDM and Non GDM study participants

As expected, maternal BMI was highly significantly positively correlated with fetal liver length for the entire sample $(\mathrm{N}=331 ; \mathrm{p}<0.001 ; \mathrm{R}=+0.55)$ as well in the sample of GDM patients $(\mathrm{N}=85 ; \mathrm{p}<0.001 ; \mathrm{R}=+0.58)$ and controls $(\mathrm{N}=246 ; \mathrm{p}<0.001 ; \mathrm{R}=+0.33)$. These correlations were presented on graph 1,2 and 3 . 


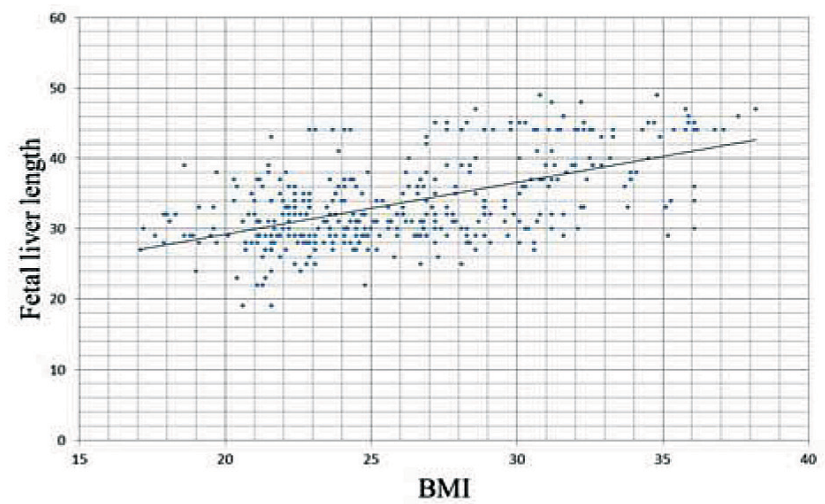

Figure 1. Correlation of maternal BMI and FLL in the whole study population

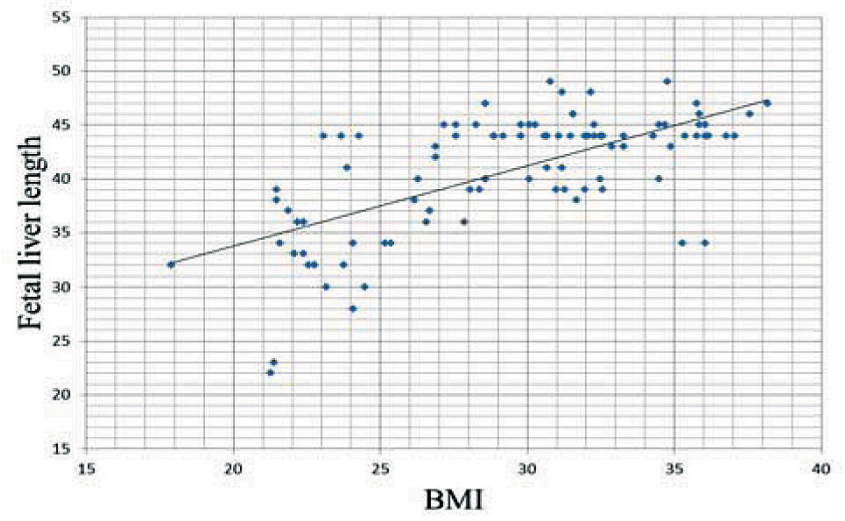

Figure 2. Correlation of maternal BMI and FLL in the GDM participants

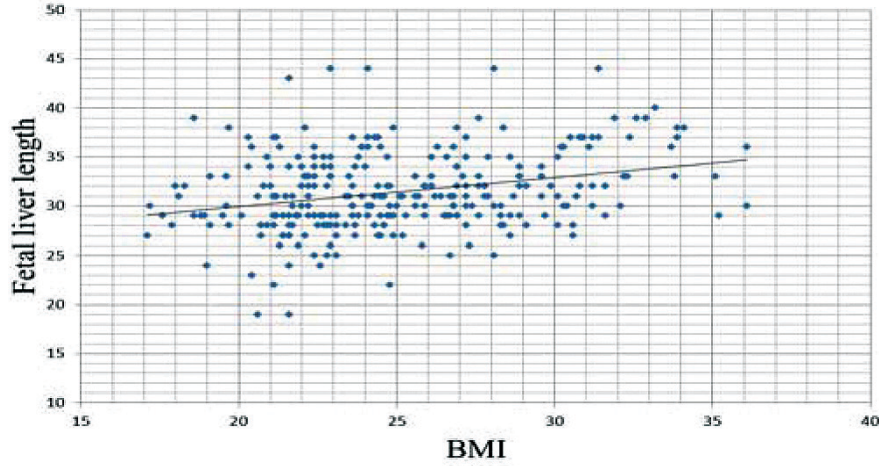

Figure 2. Correlation of maternal BMI and FLL in the Non GDM participants

\section{Conclusions}

Gestational diabetes mellitus and maternal overweight and obesity are associated with increased risk for adverse maternal and perinatal outcomes, such as fetal overgrowth. Although most studies addressing the effects of maternal BMI on adverse outcomes include women with GDM, a little is known about associations between maternal BMI and fetal metabolic status evaluated by ultrasound means. One of the ultrasound parameter of fetal metabolic and glycemic control is the measurement of FLL. Fetal liver length measurements in our study were correlated with maternal BMI.

Our study results revealed that the fetal growth is positively affected by maternal BMI, evaluated through the measurements of fetal liver length. Our finding is in accordance with other studies who addressed the other 
aspects of fetal anthropometry assess by means of ultrasound exam ${ }^{7}$. This finding is even more momentous in GDM subpopulation of study participants, were the correlation between maternal BMI and FLL is stronger. Among determinants of fetal growth in the second trimester of pregnancies complicated by GDM, maternal BMI appears to have the strongest influence on fetal growth ${ }^{8}$, which is in agreement with our findings. Fetal liver enlargement participate in structuring fetal macrosomia, and maternal obesity has been shown to be a strong independent risk factor for newborn macrosomia regardless of whether maternal glucose tolerance is normal or impaired ${ }^{9}, 10$. The explanation of the stronger correlation between maternal BMI and FLL in GDM group of study participants comparing to Non GDM participants could be find in fact that increased BMI has been associated with a decreased insulin sensitivity and peripheral hyperinsulinism and subsequent fetal macrosomia ${ }^{11}$.

\section{Conclusions}

Maternal BMI has impact on fetal liver length assessed by ultrasound exam. This influence is even higher in GDM. Further investigations are needed for the determination of the impact of maternal BMI on fetal anthropometrics and eventually in preventing offspring obesity.

\section{Literature}

1. Oken E, Gillman MW. Fetal Origins of Obesity. Obesity Research 2003; 11 (4): 496-506.

2. Catalano PM, Ehrenberg HM. The short- and long-term implications of maternal obesity on the mother and her offspring. BJOG 2006; 113(10):1126-33.

3. Gojnic M, Perovic M, Pervulov M, Ljubic A. The effects of adjuvant Insulin therapy among pregnant women with IGT who failed to achieve the desired glycemia levels by diet and moderate physical activity. The Journal of MaternalFetal \& Neonatal Medicine 2012; 25 (10): 2028-2034.

4. Dupak J, Trujillo A. Ultrasound Surveillance in Pregnancy Complicated by Diabetes. Diabetes Spectrum 2007; 20(2):89-93.

5. Boito SM, Struijk PC, Ursem NT, Stijnen T, Wladimiroff JW. Assessment of fetal liver volume and umbilical venous volume flow in pregnancies complicated by insulindependent diabetes mellitus. BJOG 2003; 110 (11):1007-13.

6. Mirghani H, Zayed R, Thomas L, Agarwal M. Gestational diabetes mellitus: fetal liver length measurements between 21 and 24 weeks' gestation. J Clin Ultrasound 2007; 35:34-37.

7. Ay L, Kruithof C, Bakker R, Steegers E, Witteman J, Moll H, Hofman A, Mackenbach J, Hokken-Koelega A, Jaddoe V. Maternal anthropometrics are associated with fetal size in different periods of pregnancy and at birth. The Generation R Study. BJOG 2009;116:953-963.

8. Schaefer-Graf U, Kjos SJ, Kilavuz MO, Plagemann A, Brauer M, Dudenhausen JW, Vetter K. Determinants of Fetal Growth at Different Periods of Pregnancies Complicated by Gestational Diabetes Mellitus or Impaired Glucose Tolerance. Diabetes Care 2003; 26 (1): 193-198.

9. Perlow J, Morgan M, Montgomery D, Towers C, Porto M. Perinatal outcome complicated by massive obesity. Am J Obstet Gynecol 1992; 167: 958-962.

10. Goldman M, Kitzmiller J, Abrams B, Cowan R, Laros R. Obstetric complications with GDM: effects of maternal weight. Diabetes 1991; 40 (Suppl. 2): 79-82.

11. Marquette G, Francoeur D, Skoll M. The incidence of fetal macrosomia in hyperinsulinemic euglycemic patients. K Matern Fetal Invest 1995; 5: 33-35.

Author for correspondence:

Milan Perovic, MD, PhD, Consultant in Gynecology and Obstetrics

Address: Obilicev venac 1, 11000, Belgrade, Serbia

Email address: perovicmilan@hotmail.com 